\title{
REFORMULASI ATURAN LARANGAN PENGUSAHA MEMBAYAR UPAH LEBIH RENDAH DARI UPAH MINIMUM
}

\author{
Mustakim $^{1}$, Tjut Dhien Shafina ${ }^{1}$ \\ ${ }^{1}$ Program Studi Ilmu Hukum, Universitas Nasional \\ email ; mustakim.unas@gmail.com, shafinacut@gmail.com
}

Korespondensi : mustakim.unas@gmail.com

\begin{abstract}
The clause of article 90 point (1) act No. 13 Year 2003 about employment that prohibit or entrepreneur to pay not lower than the minimum wage resulted in problem which is not only philosophic, but also juridical, and sociological that lead to the uncertainty and unfairness not only among the employees or worker but also entrepreneur and/or enterprise because it is found the fact that not all entrepreneurs have an ability to pay the minimum wage and the there is uncertainty and unclearness about the definition of entrepreneur (article 1 number 5) and enterprise (Article 1 number 6) Act No. 13 Year 2003 about employment. The problem of the research is what is the legal implication of article 90 point (1) UU No. 13 Year 2003 that resulted in uncertainty and unfairness for employees and employer and how to reform the clause of article 90 point (1) UU No. 13 Year 2003 about employment that prohibit entrepreneur to pay wages lower than minimum wage in order to give certainty and fairness both for employees and employers to establish work relationship? The type of the research is normative with philosophical and constitutional approach. The result found that the legal norm of the prohibition toward the entrepreneur to pay wage lower than the minimum wage needs to be reformed by giving the minimum provision for the entrepreneur that has a compulsory to pay not lower than the minimum wage.
\end{abstract}

Keywords: entrepreneur, minimum wage, worker, rule reformulation, pay sallary

\begin{abstract}
Abstrak
Ketentuan Pasal 90 ayat (1) UU Nomor 13 Tahun 2003 Tentang Ketenagakerjaan yang telah melarang atau mewajibkan pengusaha untuk membayuar upah tidak lebih rendah di bawah upah minimum menyebabkan timbulnya masalah yang tidak hanya dari aspek filosofis, yuridis dan sosiologis yang berujung pada ketidakpastian dan ketidakadilan tidak hanya dari Pekerja tetapi juga Pengusaha atau Perusahaan, dikarenakan ditemukan fakta bahwa tidak semua pengusaha mempunyai kemampuan untuk membayar upah minimum dan adanya ketidakpastian dan ketidakjelasan mengenai definisi Pengusaha (Pasal 1 angka 5) dan Pengusaha (Pasal 1 angka 6) UU No. 13 Tahun 2003 Tentang Ketenagakerjaan. Masalah dalam penelitian ini adalah apa implikasi hukum Pasal 90 ayat (1) UU No. 13 Tahun 2003 yang menimbulkan ketidakpastian dan ketidakadilan bagi pekerja dan Pengusaha dan bagaimana mereformulasi ketentuan Pasal 90 ayat (1) UU No. 13 Tahun 2003 Tentang Ketenagakerjaan yang melarang bagi pengusaha membayar upah lebih rendah dari upah minimum, sehingga dapat memberikan kepastian dan keadilan bagi pekerja dan pengusaha dalam menjalin hubungan kerja? Tipe penelitian ini adalah penelitian normatif dengan
\end{abstract}


pendekatan filosofis dan perundang-undangan. Hasil penelitian ditemukan bahwa norma hukum larangan pengusaha membayar upah dibawah upah minimum perlu direformulasi dengan memberikan ketentuan minimal bagi pengusaha yang diberikan kewajiban membayar upah minimum.

Kata kunci: pengusaha, upah minimum, pekerja, reformulasi aturan, pembayaran upah

\section{PENDAHULUAN}

Pembangunan ketenagakerjaan sebagai bagian integral dari pembangunan nasional berdasarkan Pancasila dan Undang-Undang Dasar Negara Republik Indonesia Tahun 1945 (selanjutnya disebut UUD NRI Tahun 1945), dilaksanakan dalam rangka pembangunan manusia Indonesia seutuhnya dan pembangunan masyarakat Indonesia seluruhnya untuk meningkatkan harkat, martabat, dan harga diri tenaga kerja serta mewujudkan masyarakat sejahtera, adil, makmur, dan merata, baik materiil maupun spiritual. Pembangunan ketenagakerjaan harus diatur sedemikian rupa sehingga terpenuhi hak-hak dan perlindungan yang mendasar bagi tenaga kerja dan buruh serta pada saat yang bersamaan dapat mewujudkan kondisi yang kondusif bagi pengembangan dunia usaha (Penjelasan Umum Undang-Undang No. 13 Tahun 2003 Tentan Ketenagakerjaan).

Salah satu hak pekerja adalah mendapatkan penghidupan yang layak. Penghidupan yang layak bagi seorang pekerja merupakan hak konstitusional bagi setiap warga Negara dan terukur dari berapa besaranya upah yang diterima. Pentingnya upah yang menjadi hak dari tenaga kerja menjadi alasan negara memberikan perlindungan sebagaimana tercantum dalam Undang-Undang Dasar Negara Republik Indonesia Tahun 1945 sebagai konstitusi negara, sebagai berikut :

a. Pasal 27 ayat (2) menyatakan bahwa "Tiap-tiap warga negara berhak atas pekerjaan dan penghidupan yang layak bagi kemanusiaan”.

b. Pasal 28 D ayat (2) menyatakan bahwa: "Setiap orang berhak untuk bekerja serta mendapat imbalan dan perlakuan yang adil dan layak dalam hubungan kerja".

Jaminan atas penghidupan yang layak juga ditegaskan dalam UndangUndang Pasal 88 ayat (1) Nomor 13 Tahun 2003 Tentang Ketenagakerjaan setiap buruh berhak memperoleh penghasilan yang memenuhi penghidupan yang layak bagi kemanusiaan dengan tujuan melindugi hak setiap pekerja memperoleh penghasilan untuk penghidupan yang layak, sehingga pemerintah menetapkan upah minimum yang didasarkan pada kebutuhan hidup layak di setiap daerah dan mewajibkan perusahaan untuk membayar upah tidak lebih rendah dari upah minimum sebagaimana ditegaskan Pasal 90 ayat (1) UU Ketenagakerjaan yang berbunyi "Pengusaha dilarang membayar upah lebih rendah dari upah minimum ..." (Ketentuan yang sama juga diatur Pasal 2 Keputusan Menteri Tenaga Kerja dan Transmigrasi Nomor Kep-231/Men/2003 tentang Tata Cara Penangguhan Pelaksanaan Upah Minimum).

Bahkan untuk memastikan dan mendorong terlaksananya ketentuan tersebut serta menjamin perlindungan pekerja atas upah minimum Pasal 89 UU 
Ketenagakerjaan mengamanatkan pemerintah wajib menentukan upah minimum dengan memperhatikan semua kepentingan termasuk kondisi ekonomi dan adanya ketentuan sanksi dipidana sebagaimana Pasal 185 ayat (1) UUK menyatakan:

Barang siapa melanggar ketentuan sebagaimana dimaksud dalam Pasal 42 ayat (1) dan ayat (2), Pasal 68, Pasal 69 ayat (2), Pasal 80, Pasal 82, Pasal 90 ayat (1), Pasal 143, dan Pasal 160 ayat (4) dan ayat (7), dikenakan sanksi pidana penjara paling singkat 1 (satu) tahun dan paling lama 4 (empat) tahun dan/atau denda paling sedikit Rp 100.000.000,00 (seratus juta rupiah) dan paling banyak Rp 400.000.000,00 (empat ratus juta rupiah).

Akan tetapi pengaturan tersebut menimbulkan masalah baik filosofis, yuridis, sosiologis.

Masalah filosofisnya adalah bahwa pengaturan larangan pengusaha untuk membayar upah tidak lebih rendah dari upah minimum pada dasarnya untuk memberikan perlindungan dan keadilan pekerja, untuk mencegah buruh dibayar upah sangat rendah dan tidak dijadikan komoditi (pengusaha) di tengah pasar ketersediaan jumlah tenaga kerja berlebih. Keadilan merupakan tujuan hukum, dan dalam Pancasila pada Sila ke Empat menyatakan Keadilan Sosial Bagi Seluruh Rakyat Indonesia. Keadilan sosial diwujudkan dalam kehendak untuk melaksanakan kesejahteraan umum, yakni kepada sekalian masyarakat yang meliputi warga negara dan penduduknya, termasuk pekerja buruh. Kesejahteraan pekerja terletak pada berapa nilai upah yang diterimanya, karena dengan upah itulah diharapkan pekerja dapat menghidupi dirinya, keluarganya secara layak, dan esensi upah merupakan elemen sangat penting dalam hubungan kerja. Pasal 27 ayat (2) dan Pasal 28 D ayat (2) UUD RI Tahun 1945 adalah landasan konstitusi untuk menetapkan besaran upah minimum yang dapat menghidupi pekerja secara layak. Akan tetapi justru memberikan ketidakadilan bagi pemberi kerja khususnya pengusaha dengan adanya fakta sebagian besar yang tidak mampu untuk membayar upah minimum dan adanya perusahaan yang diproses pidana akibat tidak melakasanakan ketentuan tersebut. Salah satu contoh adalah Terpidana Sdr. Ir. Bagoes Srihandhojono yang telah dijatuhkan pidana selama 1 tahun 6 bulan dan denda 200.000.000,- (dua ratus juta rupiah) subside 2 bulan penjara dikarenakan tidak membayar upah di atas upah minimum ( Putusan No. 4318/Pid.B/2009/PN. SBY, tanggal 13 April 2010 Jo. Putusan 645/Pid. B/2010/PT. SBY, tanggal 04 November 2010 Jo. Putusan No. 86 PK/PID-SUS/2013, tanggal 05 Mei 2015. Dengan demikian tujuan hukum akan keadilan menjadi tidak tercapai.

Masalah yuridisnya adalah adanya ketentuan yang tidak jelas dan kabur dari norma yang berkaitan dengan pelaksanaan ketentuan larangan pengusaha untuk membayar upah tidak lebih rendah dari upah minimum. Norma hukum yang tidak jelas atau kabur terlihat dalam Pasal 1 angka 6 menyatakan bahwa : Perusahaan adalah: a. setiap bentuk usaha yang berbadan hukum atau tidak, milik orang perseorangan, milik persekutuan, atau milik badan hukum, baik milik swasta maupun milik negara yang mempekerjakan pekerja/buruh dengan membayar upah atau imbalan dalam bentuk lain; b. usaha-usaha sosial dan usaha-usaha lain yang 
mempunyai pengurus dan mempekerjakan orang lain dengan membayar upah atau imbalan dalam bentuk lain.

Dengan demikian pengusaha perseorangan, persekutuan atau badan yang menjalankan bentuk usaha baik milik orang perseorangan, milik persekutuan, atau milik badan hukum, baik milik swasta maupun milik negara yang mempekerjakan buruh dengan membayar upah atau imbalan dalam bentuk lain wajib memberikan upah tidak lebih rendah dari upah minimum. Ketentuan ini tidak melihat potensi kemampuan masing-masing bentuk usaha untuk membayar dan menghadapi ketentuan Pasal 90 ayat (1) UUK, padahal dari segi hak dan kewajiban antara bentuk usaha yang dimaksd mempunyai hak dan kewajiban yang berbeda-beda apalagi jika dilihat dari kontek kepentingan meningkatkan dunia usaha sebagai perwujudkan kesejahteraan rakyat.

Pasal 1 Angka 4 UU Nomor 13 Tahun 2003 Tentang Ketenagakerjaan "Pemberi Kerja adalah orang perseorangan, pengusaha, badan hukum, atau badan-badan lainnya yang mempekerjakan tenaga kerja atau penyelenggara negara yang mempekerjakan pegawai negeri dengan membayar gaji, upah, atau imbalan dalam bentuk lainnya.

Jika dilihat lebih teliti dari pengertian tersebut, pembuat UU memberikan perluasan siapa yang dimakasud pemberi kerja dan dapat disimpulkan bahwa tidak semua yang mempekerjakan orang adalah pengusaha. Bahkan pembebanan kewajiban, bahkan larangan yang disertai sanksi pidana terhadap pengusaha untuk memberikan upah tidak lebih rendah dari upah minimum disebabkan pengusaha erat kaitanya dengan keuntungan sehingga wajar dan harus ada pembebanan atau pembatasan dari pemerintah dengan adanya kewajiban tersebut sebagai bentuk perlindungan terhadap pekerja.

Masalah sosiologisnya adalah banyaknya pengusaha yang tidak mampu untuk menerapkan dan membayar upah di atas upah minimum, sehingga mengakibatkan pelaksanaan kewajiban atau larangan untuk membayar upah tidak lebih rendah dari upah minimum menjadi problem di lapangan. Fakta tersebut terlihat dari adanya fakta-fakta hukum yang ditemukan berupa adanya pengusaha yang berurusan dengan hukum baik menjadi tersangka, terdakwa dan sudah diputus bersalah oleh pengadilan.

\section{Rumusan Masalah}

Berdasarkan latar belakang tersebut di atas, penulis menarik rumusan masalah dalam penelitian ini adalah :

1. Mengapa ketentuan Pasal 90 ayat (1) UU No. 13 Tahun 2003 Tentang Ketenagakerjaan yang melarang bagi pengusaha membayar upah lebih rendah dari upah minimum menimbulkan ketidakpastian dan ketidakadilan bagi pekerja dan pengusaha dalam menjalin hubungan kerja?

2. Bagaimana mereformulasi ketentuan Pasal 90 ayat (1) UU No. 13 Tahun 2003 Tentang Ketenagakerjaan yang melarang bagi pengusaha membayar upah lebih rendah dari upah minimum, sehingga dapat memberikan kepastian dan keadilan bagi pekerja dan pengusaha dalam menjalin hubungan kerja? 


\section{METODE PENELITIAN}

Penelitian ini merupakan penelitian normatif dengan mengunakan pendekatan undang-undang (statute approach) dan Pendekatan Konseptual. Bahan yang digunakan adalah bahan hukum primer yaitu bahan hukum yang autoritatif artinya mempunyai otoritas dapat juga diartikan sebagai bahan hukum yang mengikat berupa peraturan perundang-undangan diantaranya Pasal 90 ayat (1) Undang-Undang No. 13 Tahun 2003 tentang Ketenagakerjaan dan Peraturan Menteri Ketenagakerjaan, bahan hukum sekunder yaitu bahan hukum yang memberikan petunjuk terhadap bahan hukum primer dan bahan hukum sekunder, seperti kamus hukum dan Ensiklopedi hukum dan bahan tersier atau penunjang atau bahan non hukum (Johnny Ibrahim, 2006). Selanjutnya bahan hukum yang diperoleh dalam penelitian ini diuraikan dan dihubungkan sedemikian rupa, sehingga disajikan dalam penulisan yang lebih sistematis guna menjawab permasalahan yang telah dirumuskan. Pengolahan bahan hukum dilakukan secara deduktif, yakni menarik kesimpulan dari suatu permasalahan yang bersifat umum terhadap permasalahan yang dihadapi. Selanjutnya bahan hukum yang ada dianalisis secara kualitatif yaitu dengan menguraikan hasil penelitian berupa kalimat-kalimat.

\section{PEMBAHASAN DAN HASIL PENELITIAN}

\section{Ketentuan Pasal 90 Ayat (1) UU No. 13 Tahun 2003 Tentang Ketenagakerjaan Tidak Berkepastian Dan Ketidakadilan}

Baik pekerja dan pengusaha secara prinsip memiliki persamaan dalam menjalin hubungan kerja yaitu mewujudkan apa yang disebut hidup layak. Hidup layak merupakan hak konstitusional warga negara yang dijamin dalam konstitusi UUD NRI Tahun 1945. Kebutuhan hidup layak (selanjutnya disebut KHL) diatur UU No.13 tahun 2003 tentang Ketenagakerjaan dan selanjutnya dipertegas dalam Peraturan Presiden No.78 tahun 2015 tentang Pengupahan dan Peraturan Menteri Ketenagakerjaan No. 21 tahun 2016 Tentang Kebutuhan Hidup Layak.

Standarisasi hidup layak dalam hubungan kerja adalah upah. Upah adalah hak buruh yang diterima dan dinyatakan dalam bentuk uang sebagai imbalan dari pengusaha atau pemberi kerja kepada pekerja yang ditetapkan dan dibayarkan menurut suatu perjanjian kerja, kesepakatan, atau peraturan perundang-undangan, termasuk tunjangan bagi buruh dan keluarganya atas suatu pekerjaan atau jasa yang telah atau akan dilakukan (Undang-Undang No. 13 Tahun 2003 Tentang Ketenagakerjaan, Pasal 1 angka 3)

Dalam rangka mewujudkan pengasilan yang memenuhi penghidupan yang layak bagi kemanusian, pemerintah telah menetapkan kebijakan terhadap pengupahan yang melindungi pekerja. Kebijakan pengupahan yang melindungi pekerja meliputi (Maimum, 2007).

a. Upah minimum.

b. Upah kerja lembur.

c. Upah tidak masuk kerja karena berhalangan.

d. Upah tidak masuk kerja karena melakukan kegiatan lain di luar pekerjaannya; 
e. Upah karena menjalankan hak waktu istirahat kerjanya.

f. Bentuk dan cara pembayaran upah.

g. Denda dan potongan upah.

h. Hal-hal yang dapat diperhitungkan dengan upah;

i. Struktur dan skala pengupahan yang proporsional;

j. Upah untuk pembayaran pesangon; dan

k. Upah untuk perhitungan pajak penghasilan.

Upah Minimum adalah upah bulanan terendah berupa upah tanpa tunjangan atau upah pokok termasuk tunjangan tetap yang ditetapkan oleh gubernur sebagai jaring pengaman (Peraturan Menteri Ketenagakerjaan Nomor 15 Tahun 2018 tentang Upah Minimum, Pasal 1 angka 1). Pasal 89 ayat (3) Undang-Undang Nomor 13 Tahun 2003 tentang Ketenagakerjaan : Upah Minimum berdasarkan wilayah provinsi ditetapkan oleh Gubernur dengan memperhatikan rekomendasi dari Dewan Pengupahan Provinsi atau Bupati.

Sumarsono sebagaimana dikutip Devanto Shasta Pratomo Putu Mahardika Adi Saputra menyatakan:

Kebijakan Upah Minimum telah menjadi isu yang penting dalam masalah ketenagakerjaan di beberapa negara baik maju maupun berkembang. Sasaran dari kebijakan upah minimum ini adalah untuk menutupi kebutuhan hidup minimum dari pekerja dan keluarganya. Dengan demikian, kebijakan upah minimum adalah untuk (a) menjamin penghasilan pekerja sehingga tidak lebih rendah dari suatu tingkat tertentu, (b) meningkatkan produktivitas pekerja, (c) mengembangkan dan meningkatkan perusahaan dengan cara-cara produksi yang lebih efisien (Devanto Shasta Pratomo, Putu Mahardika, Adi Saputra, 2011).

Menurut Undang Undang No 13 tahun 2003 disebutkan bahwa upah minimum hanya ditujukan bagi pekerja dengan masa kerja 0 (nol) sampai dengan 1 (satu) tahun. Dari definisi tersebut, terdapat dua unsur penting dari upah minimum yaitu adalah: a) Upah permulaan adalah upah terendah yang harus diterima oleh buruh pada waktu pertama kali dia diterima bekerja. b) Jumlah upah minimum haruslah dapat memenuhi kebutuhan hidup buruh secara minimal yaitu kebutuhan untuk sandang, pangan dan keperluan rumah tangga.

Perintah pengusaha untuk membayar upah minimum ditegaskan dalam Pasal 90 ayat (1) Undang-Undang Nomor 13 Tahun 2003 tentang Ketenagakerjaan menegaskan bahwa "Pengusaha dilarang membayar upah lebih rendah dari upah minimum sebagaimana dimaksud dalam Pasal 89". Namun ketentuan tersebut masih memberikan ruang sebagaimana dinyatakan Pasal 90 ayat (2) Undang-Undang Nomor 13 Tahun 2003 tentang Ketenagakerjaan dengan memberikan kesempatan kepada pengusaha untuk melakukan penangguhan terhadap pembayaran upah minimum. Penjelasan Pasal 90 ayat (2) UU Ketenagakerjaan menyebutkan sebagai berikut: Penangguhan pelaksanaan upah minimum bagi perusahaan yang tidak mampu dimaksudkan untuk membebaskan perusahaan yang bersangkutan 
melaksanakan upah minimum yang berlaku dalam kurun waktu tertentu. Apabila penangguhan tersebut berakhir maka perusahaan yang bersangkutan wajib melaksanakan upah minimum yang berlaku pada saat itu tetapi tidak wajib membayar pemenuhan ketentuan upah minimum yang berlaku pada waktu diberikan penangguhan. Akan tetapi terkaithal tersebut Mahkamah Konstitusi dalam Putusan Nomor 72/PUU-XIII/2015 menyatakan bahwa frasa “...tetapi tidak wajib membayar pemenuhan ketentuan upah minimum yang berlaku pada waktu diberikan penangguhan" bertentangan dengan Undang-Undang Dasar 1945 dan tidak memiliki kekuatan hukum mengikat. Artinya, Mahkamah memberi penegasan selisih kekurangan pembayaran upah minimum selama masa penangguhan tetap wajib dibayar oleh pengusaha" (Tri Jata Ayu, 2019).

Ketidakpastian dari ketentuan Pasal 90 ayat (1) UU No. 13 Tahun 2003 Tentang Ketengakaerjaan adalah terdapat dalam kata "Pengusaha dilarang membayar upah lebih rendah dari upah minimum.." padahal dalam ketentuan Pasal 1 Angka 4 UU Nomor 13 Tahun 2003 Tentang Ketenagakerjaan pengusaha adalah salah satu dari subjek yang dapat memberikan pekerjaan kepada pekerja dan membayar upah sebagaimana terlihat tegas dalam Pasal 1 angka 4 UUK yang menyebutkan "Pemberi Kerja adalah orang perseorangan, pengusaha, badan hukum, atau badan-badan lainnya yang mempekerjakan tenaga kerja atau penyelenggara negara yang mempekerjakan pegawai negeri dengan membayar gaji, upah, atau imbalan dalam bentuk lainnya.

Ketidakpastian yang lain terdapat dalam Pasal 1 angka 5 UUK menegaskan bahwa Pengusaha adalah :

a. Orang perseorangan, persekutuan, atau badan hukum yang menjalankan suatu perusahaan milik sendiri;

b. Orang perseorangan, persekutuan, atau badan hukum yang secara berdiri sendiri menjalankan perusahaan bukan miliknya

c. Orang perseorangan, persekutuan, atau badan hukum yang berada di Indonesia mewakili perusahaan sebagaimana dimaksud dalam huruf a dan b yang berkedudukan di luar wilayah Indonesia.

Sedangkan Perusahaan adalah:

a. Setiap bentuk usaha yang berbadan hukum atau tidak, milik orang perseorangan, milik persekutuan, atau milik badan hukum, baik milik swasta maupun milik negara yang mempekerjakan pekerja/buruh dengan membayar upah atau imbalan dalam bentuk lain;

b. Usaha-usaha sosial dan usaha-usaha lain yang mempunyai pengurus dan mempekerjakan orang lain dengan membayar upah atau imbalan dalam bentuk lain.

\section{Implikasi Hukum Pasal 90 Ayat (1) UU No. 13 Tahun 2003 Tentang Ketengakaerjaan}

Ada beberapa implikasi hukum apabila Pengusaha tidak mematuhi ketentuan Pasal 90 ayat (1) UU No. 13 Tahun 2003 Tentang Ketengakaerjaan. Implikasi hukum tersebut adalah : 


\section{Batal Demi Hukum Perjanjian Kerja}

Hubungan kerja antara Pengusaha dan Pekerja didasarkan atas Perjanjian Kerja dengan persyaratan sebagaimana diatur dalam Pasal 1320 KUHPerdata yaitu terpenuhinya Kesepakatan dari mereka yang mengikatkan diri, Kecakapan untuk membuat suatu perikatan, Suatu hal tertentu, dan Suatu sebab yang halal dan Pasal 52 UUK perjanjian kerja harus dibuat atas dasar Kesepakatan kedua belah pihak, Kemampuan atau kecakapan melakukan perbuatan hukum, Adanya pekerjaan yang diperjanjikan dan Pekerjaan yang diperjanjikan tidak bertentangan dengan ketertiban umum, kesusilaan, dan peraturan perundang-undangan yang berlaku.

Nah ketika Perjanjian kerja itu melanggar ketentuan Pasal 90 ayat (1) UUK yangt memerintahkan Pengusaha membayar upah tidak boleh lebih rendah dari upah minimum, maka jika Pengusaha melakukan pembayaran upah lebih rendah dari upah minimum mengakibatkan Perjanjian bertentangan dengan peraturan perundang-undangan. Dengan kata lain, kesepakatan (konsensus) para pihak kausanya harus halal. Sehingga, memperjanjikan upah di bawah upah minimum antara pengusaha dengan pekerja adalah null and void atau batal demi hukum dan juga merupakan tindak pidana kejahatan Pasal 185 ayat (1) UUK dengan ancaman hukuman pidana penjara bagi pengusaha paling singkat 1 (satu) tahun dan paling lama 4 (empat) tahun dan/atau denda paling sedikit Rp.100 juta dan paling banyak Rp.400 juta.

\section{Denda dan Sanksi Pidana Bagi Perusahaan}

Ada beberapa denda yang akan diberikan oleh perusahaan nakal yang melakukan pelanggaran dalam pemberian upah minimum terhadap para pekerjanya :

a. Pemberian tambahan upah sebesar 5\% untuk masing-masing pekerja dari perusahaan. Denda ini berlaku jika pengusaha telat membayarkan gaji para pegawainya dalam jangka waktu empat hingga delapan hari.

b. Tambahan 1\% jika hingga hari kedelapan gaji juga belum dibayar,

Perusahaan yang tidak menerapkan ketentuan Pasal 90 ayat (1) UUK dapat dilaporkan ke pihak kepolisian, karena perusahaan yang membayar upah lebih rendah di bawah upah minimum merupakan tindak pidana. Perusahaan dapat diadukan atau dilaporkan pekerja yang menerima upah dibawah upah minimum dengan dasar ketentuan Pasal 185 ayat (1) UUK menyatakan:

Barang siapa melanggar ketentuan sebagaimana dimaksud dalam Pasal 42 ayat (1) dan ayat (2), Pasal 68, Pasal 69 ayat (2), Pasal 80, Pasal 82, Pasal 90 ayat (1), Pasal 143, dan Pasal 160 ayat (4) dan ayat (7), dikenakan sanksi pidana penjara paling singkat 1 (satu) tahun dan paling lama 4 (empat) tahun dan/atau denda paling sedikit Rp 100.000.000,00 (seratus juta rupiah) dan paling banyak Rp 400.000.000,00 (empat ratus juta rupiah).

Namun upaya hukum pidana adalah merupakan ultimum remedium (upaya terakhir), jadi sebaiknya baru ditempuh apabila upaya-upaya lain telah ditempuh namun tidak ada perubahan terhadap pembayaran upah sehingga pekerja tetap mengalami kerugian. 


\section{Gugatan Kekurangan Upah dan Hak Pekerja Lainya}

Bagi pekerja yang dibayar oleh perusahaan atau pengusaha di bahwah upah minimum, selain melakukan upuaya jalur hukum pidana dengan melaporkan pengusaha atau perusahaan ke pihak keplisian, juga dapat mengajukan gugatan ke Pengadilan Hubunagan Industrial terkait kekurangan upah atau hak-hak lainya.

Pengajuan gugatan ke Pengadilan Hubungan Industrial dimungkinkan dilakukan karena perselisihan terkait kekurangan dikategorikan dengan perselisihan hubungan industrial dalam hal ini perselisihan hak atau Pemutusan Hubungan Kerja (PHK) sebagaimana disebutkan Pasal 1 angka 1 Undang-Undang No. 2 tahun 2004, Perselisihan Hubungan Industrial adalah:

Perbedaan pendapat yang mengakibatkan pertentangan antara pengusaha atau gabungan pengusaha dengan pekerja atau serikat pekerja karena adanya perselisihan hak, perselisihan kepentingan, perselisihan pemutusan hubungan kerja dan perselisihan antar serikat pekerja buruh dalam satu perusahaan.

Namun sebelum mengajukan gugatan ke Pengadilan Hubungan Industrial harus terlebih dahulu melalui proses yang diatur dalam Undang-Undang No. 2 tahun 2004 dengan tahapan penyelesaian mulai dari Bipartit dan Tripartit (Konsiliasi atau Arbitrase dan Mediasi). Pasal 3 ayat (1) Undang-Undang No. 2 tahun 2004, menyebutkan bahwa perundingan bipartit merupakan ketentuan yang bersifat imperatif yang wajib dilakukan lebih dahulu oleh para pihak sebagai amanat oleh Undang-Undang No.13 tahun 2003 tentang Ketenagakerjaan. Ketentuan dalam Pasal 136 ayat (1) menyebutkan bahwa penyelesaian perselisihan hubungan industrial wajib dilaksanakan oleh pengusaha dan pekerja atau serikat pekerja buruh secara musyawarah untuk mufakat". Penyelesaian ini dapat dilakukan jika para pihak telah menempuh penyelesaian secara bipartit, akan tetapi mengalami kegagalan. Penyelesaian ini dapat dilakukan dengan alternatif pilihan yaitu mediasi, konsiliasi dan arbitrase dengan menyesuaikan perselisihan yang terjadi dan apabila tidak ada pilihan, maka mediasi akan digunakan sebagai pilihan penyelesaian dengan mediator pegawai Suku Dinas Ketenagakerjaan yang ditetapkan.

\section{Mengadakan Perundingan Bipartite}

Perundingan bipartit adalah perundingan antara buruh atau serikat buruh dengan pengusaha untuk menyelesaikan perselisihan hubungan industrial. Sedangkan perundingan bipartite menurut penjelasan Pasal 3 ayat (1) UU No. 2 Tahun 2004 adalah perundingan antara pengusaha atau gabungan pengusaha dan pekerja atau serikat pekerja/serikat buruh atau antara serikat pekerja/serikat buruh dan serikat pekerja/serikat buruh lain dalan satu perusahaan yang berselisih. Perundingan bipartite ini biasa disebut dengan istlah negosiasi atau negotiation (Farid Mua'z, 2005). Abdul Khakim menyatakan bahwa :

Bipartit dalam hal sebagai mekanisme adalah tata cara atau proses perundingan yang dilakukan antara dua pihak, yaitu pihak pengusaha 
dengan pihak pekerja/buruh atau serikat pekerja/serikat buruh, antara lain apabila terjadi perselisihan antara pengusaha dengan pekerja/buruh di perusahaan (Abdul Khakim, 2007).

Apabila upaya bipartit terjadi kesepakatan, maka dibuat kesepakatan tertulis yang selanjutnya harus didaftarkan ke Pengadilan Hubungan Industrial di wilayah dimana perusahaan berada atau tempat dimana pekerja bekerja untuk mendapatkan kekuatan eksekutorial, akan tetapi apabila bipartit tidak mendapatkan kesepakatan, maka para pihak baik pengusaha ataupun pekerja dapat mengajukan permohonan ke Suku Dinas di Wilayah hukum perusahaan berada atau tempat dimana pekerja bekerja untuk dilakukan Tripartit.

\section{Pengaduan Pekerja Ke Suku Dinas Tenaga Kerja}

Penyelesaian ini dapat dilakukan jika para pihak telah menempuh penyelesaian secara bipartit, akan tetapi mengalami kegagalan. Penyelesaian secara Tripartit mempunyai tiga pilihan hukum sebagaimana dijelaskan dalam UndangUndang No. 2 tahun 2004 yaitu penyelesaian melalui Konsiliasi, Arbitrasi dan Mediasi, dimana sesuai dengan prinsip kebebasan untuk memiih jenis penyelesaian itu semua diserahkan kepada para pihak untuk memilih dan tentunya disesuaikan dengan jenis perselisihan yang dialami.

Menurut UU No. 2 Tahun 2004, pihak ketiga sebagai pihak yang dilibatkan untuk menyelesaikan suatu perselisihan hubungan industrial adalah mediator, konsiliator dan arbiter hubungan industrial.

Langkah pertama yang harus dilakukan oleh para pihak mencatatkan hal tersebut dan kemudian instansi yang bertanggung jawab di bidang ketenagakerjaan setempat wajib menawarkan kepada para pihak untuk menyepakati memilih penyelesaian melalui konsiliasi atau melalui arbitrase.

Penyelesaian melalui konsiliasi dapat digunakan oleh para pihak yang berselisih terhadap perselisihan kepentingan, perselisihan pemutusan hubungan kerja, atau perselisihan antar serikat pekerja/serikat buruh, sedangkan penyelesaian melalui arbitrase dilakukan untuk penyelesaian perselisihan kepentingan atau perselisihan antar serikat pekerja/serikat buruh, akan tetapi penawaran untuk mengunakan penyelesaian melalui Konsiliasi ataupun Arbitrase tersebut tidak digunakan, maka mekanisme yang tersedia adalah penyelesaian melalui mediasi.

\section{Reformulasi Pengaturan Pembayaran Upah Pekerja Yang Berkepastian dan Berkeadilan}

Hubunungan industrial pada dasarnya adalah proses terbinannya komunikasi, konsultasi musyawarah serta berunding dan ditopang oleh kemmapuan dan komitmen yang tinggi dari smua elemen yang ada di dalam perusahaan. UndangUndang Ketenagakerjaan telah mengatur prinsip-prinsip dasar yang perlu dikembangkan dalam hubungan industrial. Arahnya adalah untuk menciptakan sistem dan kelembagaan yang ideal, sehingga tercipta kondisi kerja yang kondusif, harmaonis, dinamis dan berkadilan (Andrian Sutedi, 2009). 
Hubungan harmonis dan seimbang akan menyingkirkan jauh-jauh konsep perimbangan kekuatan apalagi pertentangan. Selanjutnya yang ditumbuh kembangkan adalah hubungan industrial yang dapat mewujudkan peningkatan produktifitas sikap kebersamaan, kepatutan, dan rasa keadilan, sehingga yang diperlukan adalah saling menghormati, saling mengerti hak dan kewajiban dalam proses dan saling membantu untuk meningkatkan nilai tambah perusahaan dalam menghadapi persaingan.

Keberadaan Pasal 90 ayat (1) UUK menimbulkan dampak hubungan industrial tidak sesuai dengan maksud dan tujuan hubungan antara pengusaha dan pekerja dan nilai-nilai Pancasila dan tujuan negara indonesia sebagai negara hukum yang bertujuan selain melindungi segenap bangsa dan seluruh tumpah darah Indonesia dengan menciptakan ketentraman dan ketertiban, juga berfungsi memajukan kesejahteraan umum, mencerdaskan kehidupan bangsa dengan mewujudkan kemakmuran yang adil bagi seluruh rakyat indonesia (Abdul Manan, 2016).

Perintah untuk membayar upah tidak lebih rendah dari upah minimum hanya ditekankan kepada pengusaha sebagaimana terlihat dalam Pasal 90 ayat (1) UndangUndang Nomor 13 Tahun 2003 tentang Ketenagakerjaan menegaskan bahwa "Pengusaha dilarang membayar upah lebih rendah dari upah minimum sebagaimana dimaksud dalam Pasal 89", padahal tidak hanya pengusaha yang dapat memberikan pekerjaan jika merujuk pada Pasal 1 Angka 4 UU Nomor 13 Tahun 2003 Tentang Ketenagakerjaan "Pemberi Kerja adalah orang perseorangan, pengusaha, badan hukum, atau badan-badan lainnya yang mempekerjakan tenaga kerja atau penyelenggara negara yang mempekerjakan pegawai negeri dengan membayar gaji, upah, atau imbalan dalam bentuk lainnya.

Ketidakpastian dan ketidakjelasan rumusan juga terlihat Pasal 1 angka 5 UUK dan Pasal 1 angka 6 UUK. Pasal 1 angka 5 Pengusaha adalah:

a. Orang perseorangan, persekutuan, atau badan hukum yang menjalankan suatu perusahaan milik sendiri;

b. Orang perseorangan, persekutuan, atau badan hukum yang secara berdiri sendiri menjalankan perusahaan bukan miliknya

c. Orang perseorangan, persekutuan, atau badan hukum yang berada di Indonesia mewakili perusahaan sebagaimana dimaksud dalam huruf $a$ dan $b$ yang berkedudukan di luar wilayah Indonesia.

Pasal angka 6 menyebutkan Perusahaan adalah:

a. Setiap bentuk usaha yang berbadan hukum atau tidak, milik orang perseorangan, milik persekutuan, atau milik badan hukum, baik milik swasta maupun milik negara yang mempekerjakan pekerja/buruh dengan membayar upah atau imbalan dalam bentuk lain;

b. Usaha-usaha sosial dan usaha-usaha lain yang mempunyai pengurus dan mempekerjakan orang lain dengan membayar upah atau imbalan dalam bentuk lain. 
G. Radbruch, dikutip Muhammad Erwin, menjelaskan bahwa sesuatu yang dibuat pasti memiliki cita atau tujuan hukum termasuk hukum yang mempunyai tiga tujuan yaitu : keadilan untuk keseimbangan, kepastian untuk ketetapan dan kemanfaatan untuk kebahagian (Muhamad Erwin, 2013). Akan tetapi keberadaan Pasal 90 ayat (1) justru menimbulkan ketidakpastian dan ketidakadilan.

Terkait keadilan, Plato mengemukakan bahwa "keadilan adalah nilai kebajikan yang tertinggi (Roscoe Pound, 1952).

Hukum yang bagus yaitu hukum yang dapat memenuhi rasa keadilan yang selalu berkembang mengikuti nilai keadilan manusia. Kesadaran hukum masyarakat akan timbul apabila ada kesesuaian antara keadilan yang hidup di dalam masyarakat dengan keadilan yang ingin dicapai oleh hukum yang sedang berlaku. Oleh karena itu kepastian hukum hendaknya harus selalu ditegakkan, karena dalam kepastian hukum itu terkandung nilai keadilan hukum. Antara kepastian dan keadilan merupakan dua sisi yang tidak dapat dipisahkan, karenanya keduanya saling mengisi.

Muhaimin Iskandar menyatakan bahwa sistem pengupahan yang baik mestinya harus memberikan ruang bagi peningkatan kesejahteraan kesejahteraan pekerja, namun tetap memperhitungkan kemampuan pengusaha agar proses produksi dari industri tetap berjalan normal dan memberikan keuntungan bagi pengusaha (Imam Rodisi : 2013).

Sesuai dengan UU No. 12 Tahun 2011 Tentang Pembentukan Peraturan Perundang-Undangan, untuk dikatakan baik norma hukum itu harus memenuhi asasasas baik materi muatan maupun asas pembentukan peraturan sebagaimana dijelaskan dalam Pasal 5 dan 6. Dari asas-asas yang disebutkan dalam Pasal 5 dan Pasal 6 UU terdapat asas-sasas yang tidak terpenuhi dalam Pasal 90 ayat (1) UU K yang menyebutkan "“'Pengusaha dilarang membayar upah lebih rendah dari upah minimum sebagaimana dimaksud dalam Pasal 89" yaitu :

a. Asas dapat dilaksanakan adalah bahwa setiap Pembentukan Peraturan Perundang-undangan harus memperhitungkan efektifitas Peraturan Perundang-undangan tersebut di dalam masyarakat, baik secara filosofis, yuridis maupun sosiologis

b. Asas kejelasan rumusan adalah bahwa setiap Peraturan Perundang-undangan harus memenuhi persyaratan teknis penyusunan Peraturan Perundangundangan sistematika dan pilihan kata atau terminologi, serta bahasa hukumnya jelas dan mudah dimengerti, sehingga tidak menimbulkan berbagai macam interpretasi dalam pelaksanaannya.

c. Asas keadilan adalah bahwa setiap Materi Muatan Peraturan Perundangundangan harus mencerminkan keadilan secara proporsional bagi setiap warga negara tanpa kecuali.

d. Asas ketertiban dan kepastian hukum adalah bahwa setiap Materi Muatan Peraturan Perundang-undangan harus dapat menimbulkan ketertiban dalam masyarakat melalui jaminan adanya kepastian hukum. 
Penulis berharap bahwa pemerintah dalam menetapkan kebijakan upah tidak hanya bertujuan untuk menjamin standar kehidupan yang layak bagi pekerja/buruh dan keluarganya, tetapi diharapkan pula dapat meningkatkan produktivitas kerja perusahaan dan meningkatkan daya beli masyarakat.

Dengan demikian, Pasal 90 ayat (1) UUK harus ada batasan-batasan dalam memerintah pengusaha dalam melakukan pembayaran upah tidak lebih rendah dari upah minimum, sehingga tidak mematikan pengusaha-pengusaha perorangan dalam menumbuhkan usahanya serta ikut andil dalam mewujudkan tujuan bangsa sesuai nilai-nilai Pancasila dan UUD NRI Tahun 1945.

\section{SIMPULAN DAN SARAN}

\section{Simpulan}

a. Kententuan yang melarang Pengusaha membayar upah di bawah lebih rendah dari upah minimum sebagaimana diatur Pasal 90 ayat (1) UU No. 13 Tahun 2003 Tentang Ketenagakerjaan menimbulkan ketidakpastian dan ketidakadilan dan tidak memenuhi asas-asas baik materi maupun asas pembentukan peraturan perundangan dan berakibat menimbulkan kondisi lemahnya iklim usaha dikarenakan ketidakmampuan dan ketakutan bagi pengusaha untuk mempekerjaan pekerja, sehingga mengakibatkan batal demi hukum perjanjian kerja, denda dan snksi pidana serta munculnya gugatan atas kurangnya upah yang belum dibayar dan tuntutan lainya terkait pemutusan hubungan kerja.

b. Mereformulasi ketentuan Pasal 90 ayat (1) UU No. 13 Tahun 2003, perlu di refourmulasi dengan menyesuaikan prinsip dan asas dalam UU No. 12 Tahun 2012 Tentang Pembentukan Peraturan Perundang-Undangan, nilai-nilai Pancasila dan UUD NRI Tahun 1945.

\section{Saran}

a. Pengusaha dan Pekerja meningkatkan hubungan yang harmonis dengan mengendepankan prinsip-prinsip dan nilai-nilai yang terkandung dalam hubungan industrial Pancasila.

b. Hubungan Industrial mencari format ketentuan terkait pelaksanaan upah minimum pekerja sehingga memberikan kondisi atau iklim pelaksanaan hubungan kerja menjadi lebih baik dan harmonis,

c. Mekukan perubahan ketentuan Pasal 90 ayat (1) UU No. 13 Tahun 2003 Tentang Ketengakaerjaan dengan perubahan sebagai berikut: Pengusaha dilarang membayar upah lebih rendah dari upah minimum sebagaimana dimaksud dalam Pasal 89 kecuali mendapatkan persetujuan oleh Pengawas Ketenagakerjaan dengan memenuhi kriteria yang ditentukan oleh Peraturan Menteri.

\section{DAFTAR PUSTAKA}

Andrian Sutedi. (2009). Hukum Perburuhan. Jakara: Sinar Grafika. 
Erwin, Muhamad. (2013). Filsafat Hukum, Releksi Kritis Terhadap Hukum. Cetakan 3. Jakarta: Rajagrafindo.

Hakhim, Abdul. (2017). Pengantar Hukum Ketenagakerjaan Indonesia Berdasarkan Undang-Undang No. 13 tahun 2003 tentang Ketenagakerjaan. Cet. II. Bandung: PT. Citra Aditya Bhakti

Ibrahim, Johnny. (2006). Teori \& Metodologi Penelitian Hukum Normatif. Jakarta: Bayumedia.

Indonesia, Peraturan Menteri Ketenagakerjaan Nomor 1 Tahun 2017 tentang Struktur dan Skala Upah.

Indonesia, Keputusan Menteri Tenaga Kerja dan Transmigrasi Nomor Kep231/Men/2003 tentang Tata Cara Penangguhan Pelaksanaan Upah Minimum

Maimun. (2007). Hukum Ketenagakerjaan Suatu Pengantar. Jakarta, Pradaya.

Mu'adz, Farid. (2005). Pengadilan Hubungan Industrial Dan Alternatif Penyelesaian Perselisihan Hubungan Industrial di Luar Pengadilan. Jakarta : Ind-Hill-Co.

Pound, Roscoe. (1952). Justice According to Law. New Haven London:Yale University Press.

Pratomo, Devanto Shasta dan Putu Mahardika, Adi Saputra. (2011). Kebijakan Upah Minimum Untuk Perekonomian Yang Berkeadilan : Tinjaun UUD 1945. Fakultas Ekonomi \& Bisnis Universitas BrawijayaJournal of Indonesian Applied Economics Vol. 5 No. 2.

Pramesti, Tri Jata Ayu. (2019). Langkah Hukum Jika Upah di Bawah Standar Minimum, Senin, 28 January. Lihat di https://www.hukumonline.com/klinik/detail/ulasan/lt4c85f88b626af/lang kah-hukum-jika-upah-di-bawah-standar-minimum.

Putusan No. 4318/Pid.B/2009/PN. SBY, tanggal 13 April 2010 Jo. Putusan 645/Pid. B/2010/PT. SBY, tanggal 04 November 2010 Jo. Putusan No. 86 PK/PID-SUS/2013.

Rodisi, Imam. (2013). Sistem Upah Harus Jamin Keadilan Pekerja \& Pengusaha, OKE Finance, Kamis 18 April 16:57 WIB https://economy.okezone.com/read/2013/04/18/320/793817/sistem-upahharus-jamin-keadilan-pekerja-pengusaha. 